\title{
3,3'-Diindolylmethane and its derivatives: nature- inspired strategies tackling drug resistant tumors by regulation of signal transduction, transcription factors and microRNAs
}

\author{
Bernhard Biersack \\ Organic Chemistry 1, University of Bayreuth, Bayreuth 95440, Germany.
}

Correspondence to: Dr. Bernhard Biersack, Organic Chemistry 1, University of Bayreuth, Universitätsstrasse 30, Bayreuth 95440, Germany. E-mail: bernhard.biersack@yahoo.com

How to cite this article: Biersack B. 3,3'-Diindolylmethane and its derivatives: nature-inspired strategies tackling drug resistant tumors by regulation of signal transduction, transcription factors and microRNAs. Cancer Drug Resist 2020;3:867-78.

http://dx.doi.org/10.20517/cdr.2020.53

Received: 21 Jul 2020 First Decision: 24 Aug 2020 Revised: 31 Aug 2020 Accepted: 22 Sep 2020 Available online: 12 Oct 2020

Academic Editor: Shrikant Anant Copy Editor: Cai-Hong Wang Production Editor: Jing Yu

\begin{abstract}
Indoles of cruciferous vegetables are promising anti-tumor agents. Studies with indole-3-carbinol and its dimeric product, 3,3'-diindolylmethane (DIM), suggest that these compounds have the ability to deregulate multiple cellular signaling pathways that are essential for tumor growth and spread. These natural compounds are also effective modulators of transcription factors and non-coding RNAs. These effects explain their ability to inhibit tumor spread and to overcome drug resistance. In this work, pertinent literature on the effects of DIM and its synthetic derivatives on resistant tumors and resistance mechanisms in tumors is highlighted.
\end{abstract}

Keywords: Indole, 3,3'-diindolylmethane, drug resistance, anticancer drugs, microRNAs

\section{INTRODUCTION}

Cancer is one of the most serious human health concerns. The current treatments of cancer comprise of surgery, radiation therapy, chemotherapy with classical cytotoxic drugs and/or targeted drugs (e.g., protein kinase inhibitors), endocrine therapy, and immunotherapy ${ }^{[1-3]}$. However, efficient cancer treatment with chemotherapeutics is hampered by drug resistance. The formation of tumor resistance is complex and based

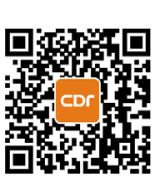




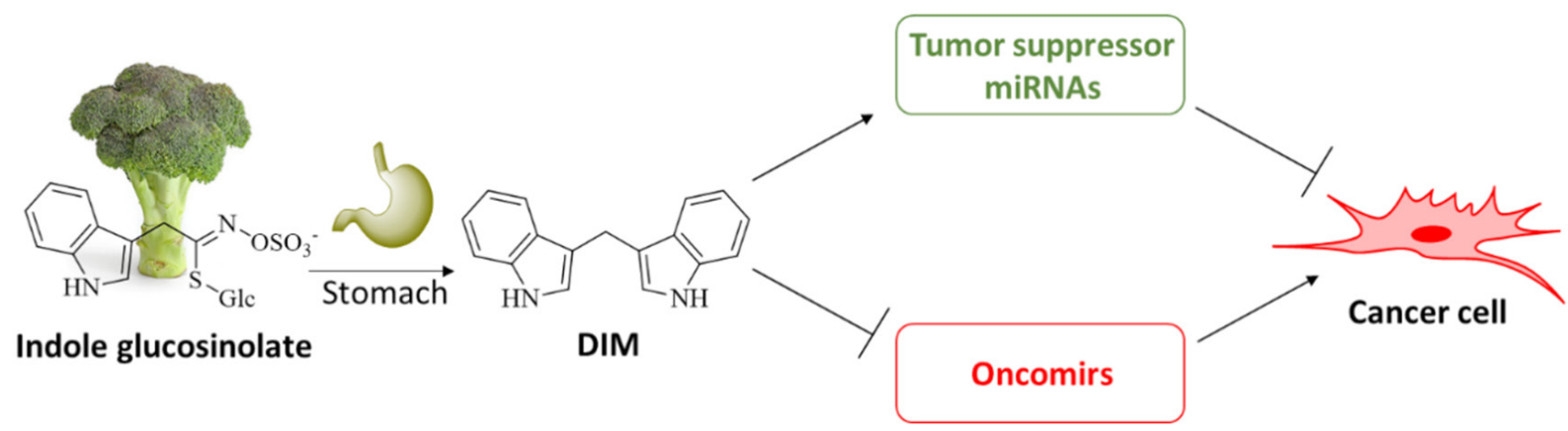

Figure 1. Natural indole glucosinolates form 3,3'-diindolylmethane (DIM) in the stomach, which suppresses tumor growth and overcomes tumor resistance by induction of tumor suppressor miRNAs and suppression of oncomirs

on intrinsic and acquired resistance mechanisms which include increased efflux of chemotherapeutics (e.g., by $\mathrm{ABC}$ transporters), increased DNA repair, mutation or alteration of drug targets, epigenetic mechanisms such as epigenetic regulation of gene expression and/or of protein drug targets, induction of senescence, factors in the tumor microenvironment, and epithelial-to-mesenchymal transition ${ }^{[4,5]}$. In order to overcome these resistance factors, thorough knowledge of these mechanisms is necessary in addition to the identification of new drugs. Nature-derived indole compounds have shown great potential as anticancer agents, and indole alkaloid drugs such as vincristine and vinblastine are well established for the treatment of tumor diseases since many years ${ }^{[6,7]}$. The indole-based protein kinase inhibitors sunitinib (approved for the treatment of metastatic renal cell carcinoma) and enzastaurin were developed based on the natural lead indole derivative staurosporin ${ }^{[8-10]}$. Indoles are also prominent dietary compounds, and indole alkaloid derivatives of Brassica species such as indole glucosinolates, indole-3-carbinol (I3C), and 3,3'-diindolylmethane (DIM) display distinct anticancer activities based on apoptosis induction as well as suppression of phosphatidyl-inositol-3-kinase(PI3K)/Akt and nuclear factor $\kappa \mathrm{B}(\mathrm{NF}-\kappa \mathrm{B})$ signaling $[\text { Figure } 1]^{[11-13]}$. Long ago, Cato the Elder recommended cabbage leafs for the treatment of cancerous ulcers and statistics now show that populations with increased consumption of cruciferous vegetables showed lower cancer incidences ${ }^{[13-15]}$. The natural indole glucosinolates decompose into I3C and form DIM in the stomach upon consumption. However, the bioavailability of DIM is poor and formulations are often necessary for in vivo tests ${ }^{[11,16]}$. Synthetic derivatives of DIM have been prepared by various synthetic methods ${ }^{[17,18]}$. Several DIM derivatives have revealed high activities against cancer cells ${ }^{[7,19]}$. The current state of the anticancer activities of DIM and its synthetic derivatives is presented in this review with a focus on cancer drug resistance, tumor growth inhibition, and new insights concerning their effects on signaling pathways and transcription factors.

\section{DIM AND CANCER DRUG RESISTANCE - THE ROLE OF MICRO-RNAS}

The general anticancer properties of DIM based on mechanisms such as apoptosis induction, blocking of $\mathrm{NF}-\kappa \mathrm{B}, \mathrm{Akt}$ and Wnt signaling, effects on PI $3 \mathrm{~K} / \mathrm{Akt} / \mathrm{mTOR}$ signaling and aryl hydrocarbon receptor (Ahr) signaling as well as antioxidant properties have already been reviewed ${ }^{[7,11,20,21]}$. DIM has also been shown to prevent liver cancer formation and protect hepatic tissues by suppression of TGF- $\beta, \operatorname{Smad} 2 / \mathrm{Smad} 3$, AP-1, and NADPH ${ }^{[22]}$. Formulated DIM (BR-DIM or B-DIM = BioResponse-DIM) was well tolerated by healthy individuals and reached clinical trials for the treatment of prostate cancer and breast cancer ${ }^{[11,23,24]}$. In non-metastatic castrate-resistant prostate cancer patients, BR-DIM was quickly absorbed (within 2 to $4 \mathrm{~h}$ ) and led to prostate-specific antigen (PSA) reduction, however, eventual progression was observed ${ }^{[25]}$. Another study of BR-DIM in prostatectomy patients with prostate cancer showed that BR-DIM was well tolerated, and DIM was detected in prostate biopsies and blood plasma. Interestingly, $96 \%$ of the treated patients showed exclusion of the androgen receptor from the cell nucleus, and $71 \%$ of the treated patients exhibited reduced PSA levels ${ }^{[26]}$. Likewise, BR-DIM was well tolerated in prostate cancer patients 
Table 1. Effects of DIM on miRNA expression in tumors

\begin{tabular}{|c|c|c|c|}
\hline Tumor & miRNA & miRNA regulation & Targets \\
\hline \multirow[t]{4}{*}{ Prostate cancer } & let-7 & up & $\mathrm{EZH} 2$ \\
\hline & miR-34a & up & Notch-1, AR \\
\hline & miR-150-5p & up & Ahr \\
\hline & miR-92a & down & RANKL \\
\hline \multirow[t]{3}{*}{ Breast cancer } & miR-200 & up & FoxM1 \\
\hline & miR-212/132 cluster & up & Sox 4 \\
\hline & miR-21 & up & Cdc25A \\
\hline \multirow[t]{4}{*}{ Pancreatic cancer } & let-7b/c/d/e & up & ZEB-1, E-cadherin \\
\hline & $\mathrm{miR}-200 \mathrm{~b} / \mathrm{c}$ & up & ZEB-1, E-cadherin \\
\hline & miR-146a & up & MTA2, NF- $\kappa$ B, IRAK1, EGFR \\
\hline & miR-221 & down & PTEN, PUMA, p27, p57 \\
\hline
\end{tabular}

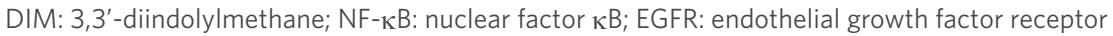

undergoing prostatectomy, DIM was detected in the blood plasma and the prostate tissue, and it increased the 2-hydroxyestrone (2-OHEI) to 16-hydroxyestrone (16 $\alpha$-OHEI) ratio as well as the levels of metabolic enzymes including CYP1 $\mathrm{A}_{1}$ and $\mathrm{CYP} 2 \mathrm{~B}_{6}{ }^{[27]}$. Breast cancer patients who received BR-DIM together with tamoxifen showed increased serum androgen hormone binding globulin levels and 2/16 $\alpha$-OHEI ratio ${ }^{[28]}$.

Research on the effects of DIM on microRNAs (miRNAs), which regulate the expression of cancer cell targets of oncologic relevance, found substantial results. There are both tumor suppressor miRNAs and oncogenic miRNAs (oncomirs), which underline the role of miRNAs as a tool for the circumvention of drug resistance by DIM [Figure 1] ${ }^{[29]}$. Hence, a concise summary of the effects of DIM on miRNA expression in various tumor models is given in Table 1.

Various tumor suppressing miRNAs were upregulated by DIM or formulated BR-DIM [Table 1]. For instance, BR-DIM inhibited prostate tumor growth by upregulation of the tumor suppressor miRNA let-7, which led to the down-regulation of $\mathrm{EZH} 2$, a histone-lysine $\mathrm{N}$-methyltransferase target of let-7 in prostate cancer patients $^{[30]}$. In castrate-resistant prostate cancer cells, DIM induced the expression of miR-34a which was accompanied by decreased self-renewal of prostate cancer cells and suppression of Notch-1 and androgen receptor signaling ${ }^{[31]}$. DIM also promoted an Ahr-mediated expression of the tumor suppressor miR-150-5p in prostate cancer cells ${ }^{[32]}$. A modulation of the expression of miRNAs was also observed in breast cancer models. When combined with herceptin, DIM upregulated the expression of the tumor suppressor miR-200, associated with apoptosis induction and FoxM1 suppression in HER-2/neu expressing SKBR3 and MDA-MB-468 breast carcinoma cells ${ }^{[33]}$. An Ahr-mediated induction of miR-212/132 cluster expression was also promoted by DIM in the drug-resistant breast cancer models T47D and MDA-MB-231, which led to downregulation of the pro-metastatic SRTY-related HMG-box 4 (Sox4) protein. These effects were observed in vitro and in vivo, and aside from reduced tumor growth, the formation of metastases was inhibited as well ${ }^{[34]}$. In gemcitabine-resistant pancreatic cancer cells (MiaPaCa-2), DIM upregulated the expression of E-cadherin and suppressed zinc finger E-box binding homeobox 1 (ZEB1), vimentin, and slug, leading to a reversal of epithelial-to-mesenchymal transition ${ }^{[35]}$. These effects were correlated with an upregulation of the tumor suppressors let-7b, let-7c, let-7d, let-7e, and miR-200b/c by DIM. In addition, DIM inhibited cancer cell invasion by suppression of metastasis-associated protein 2 (MTA2), NF- $\kappa$ B, interleukin 1 receptor-associated kinase 1 (IRAK1), and epidermal growth factor receptor (EGFR) based on upregulation of miR-146a ${ }^{[36]}$.

The suppressing effects of DIM on the expression of oncogenic miRNAs/oncomirs are also shown in Table 1. DIM blocked prostate cancer bone metastasis formation by suppression of receptor activator of nuclear factor- $\kappa \mathrm{B}$ ligand (RANKL) signaling and downregulation of miR-92a ${ }^{[37]}$. The oncomir miR-221 was 
suppressed by DIM in pancreatic cancer cells (MiaPaCa-2), and the upregulation of miR-221 targets such as phosphatase and tensin homolog deleted on chromosome (PTEN), p53 upregulated modulator of apoptosis (PUMA), and the cyclin-dependent kinase (CDK) inhibitors p27 and p57 was observed ${ }^{[38]}$. MiR-21 is a well described oncomir; however, DIM enhanced the expression of miR-21 in order to inhibit cancer cell growth and to promote Cdc25A degradation in breast cancer cells ${ }^{[39]}$. Nevertheless, molecular docking and molecular dynamics simulation calculations revealed that DIM can form interactions with the bases of the pre-miR-21, the precursor of miR-21, and the structure of DIM can be applied for the development of small molecule antagonists of miR-2 $1^{[40]}$.

\section{SYNTHETIC DIM DERIVATIVES AND CANCER DRUG RESISTANCE}

Synthetic derivatives of DIM were prepared in order to obtain more anti-tumor active compounds [Figure 2]. A simple phenyl-substituted DIM derivative, 2,2'-diphenyl-3,3'-diindolylmethane 1 (DPDIM), inhibited the growth of MDA-MB-231 triple-negative breast cancer (TNBC) cells $\left(\mathrm{IC}_{50} \mathrm{ca} .10 \mu \mathrm{mol} / \mathrm{L}\right.$; triple-negative refers to breast tumor cells lacking ER/estrogen receptor and PR/progesterone receptor, and no HER-2 overexpression). The bioavailability of 1 was high enough to reduce DMBA-induced breast tumor growth in rats at doses of $5 \mathrm{mg} / \mathrm{kg}$. The anti-tumor activity of 1 is based on the induction of apoptosis via suppression of EGFR signaling. Docking studies revealed that 1 can bind to the ATP-binding site of EGFR ${ }^{[41]}$. Halogensubstituted DIM derivatives 2a-d were prepared and tested for their activity against prostate cancer. All four compounds inhibited the growth of LNCaP prostate cancer cells in the presence of dihydrotestosterone (DHT) and suppressed PSA release. Compounds $2 \mathrm{a}$ and $2 \mathrm{~b}$ also suppressed androgen receptor expression in the prostate cancer cells $\mathrm{s}^{[42]}$. In addition, compounds $2 \mathrm{a}-\mathrm{d}$ induced apoptosis and necrosis in androgendependent and androgen-independent prostate cancer cells by activation of caspases-3, -8, and -9, and induced expression of Fas, FasL, DR4, and DR5 ${ }^{[43]}$. Compounds $2 \mathrm{a}$ and $2 \mathrm{~d}$ also induced autophagy in prostate cancer cells by activation of AMP-activated kinase (AMPK) signaling and astrocyte elevated gene $1(\mathrm{AEG}-1)^{[44]}$.

Aryl substituents at the bridging methylene group of DIM can be easily introduced by reaction of indole with the corresponding aryl aldehyde. Safe et al. ${ }^{[19]}$ have prepared a series of such anti-tumor active DIM derivatives [Figure 2]. For instance, para-substituted phenyl derivatives such as $3 \mathrm{a}$ and $3 \mathrm{~b}$ were identified as PPAR $\gamma$ activators with distinct activity against SW480 colon cancer cells. But in contrast to I3C and DIM, these synthetic compounds activated Akt. In addition, $3 \mathrm{~b}(20 \mathrm{mg} / \mathrm{kg})$ inhibited the growth of SW480 tumors in vivo and the tumor remnants showed upregulated caspase-3 and non-steroidal antiinflammatory drug activated gene 1 (NAG-1 $)^{[45]}$. The anisyl analog $3 \mathrm{c}$ activated the orphan nuclear receptor NR4A1 (Nur77, TR3) in pancreatic tumors and inhibited the growth L3.6pL pancreatic tumors in mice at a dose of $25 \mathrm{mg} / \mathrm{kg} /$ day by NR4A1-dependent induction of apoptosis. Hence, both $3 \mathrm{~b}$ and $3 \mathrm{c}$ have sufficient bioavailability in order to exert visible tumor growth inhibition and in vivo effects. The expression of several growth inhibitory and pro-apoptotic factors such as activating transcription factor 3(ATF3), p21, tumor necrosis factor-related apoptosis inducing ligand (TRAIL), and Fas ligand was induced by $3 \mathrm{c}^{[46]}$. In contrast to that, the phenol analog $3 \mathrm{~d}$ was identified as an NR4A1 antagonist. Because phenol $3 \mathrm{~d}$ is prone to metabolism, the 3-chloro-5-methoxyphenyl derivative 3e was prepared, which was distinctly more active than $3 \mathrm{~d}$ against MDA-MB-231 breast tumors in vitro and in vivo. Compound 3e suppressed NR4A1 activity, induced p21 expression, and inhibited MDA-MB-231 xenograft tumor growth at low doses of $2 \mathrm{mg} / \mathrm{kg} / \mathrm{day}$, indicating a sufficient bioavailability of $3 \mathrm{e}^{[47]}$. The close 4-chlorophenyl analog $3 \mathrm{f}$ selectively activated NR4A2 (Nurr1) in pancreatic cancer cells and had only marginal effects on NR4A1 and NR4A3 activity ${ }^{[48]}$. In addition, $3 \mathrm{f}$ was no substrate of the cancer drug resistance associated drug efflux transporter Pgp/ MDR1/ABCB1 (permeability glycoprotein, multidrug resistance protein 1, ATP-binding cassette sub-family B member 1$)^{[49]}$.

The 4-pyridyl compound 4 showed stronger activation of the orphan receptor chicken ovalbumin upstream promoter-transcription factor I (COUP-TFI) in breast cancer cells than its 3-pyridyl and 2-pyridyl 
<smiles>c1ccc(-c2[nH]c3ccccc3c2Cc2c(-c3ccccc3)[nH]c3ccccc23)cc1</smiles>

1 (DPDIM)

$\mathrm{IC}_{50} \sim 10 \mu \mathrm{M}(\mathrm{MDA}-\mathrm{MB}-231)$<smiles>[R]c1ccc([R])c2c(Cc3c[nH]c4c([R])ccc([R])c34)c[nH]c12</smiles>

$\mathrm{IC}_{50}(\mathrm{LNCaP})$ :

2a: $\mathrm{R}^{1}=\mathrm{Br}, \mathrm{R}^{2}=\mathrm{H} ; \quad 11.7 \mu \mathrm{M}$

2b: $\mathrm{R}^{1}=\mathrm{H}, \mathrm{R}^{2}=\mathrm{Br} ; \quad 15.3 \mu \mathrm{M}$

2c: $\mathrm{R}^{1}=\mathrm{Cl}, \mathrm{R}^{2}=\mathrm{H} ; \quad 14.2 \mu \mathrm{M}$

2d: $\mathrm{R}^{1}=\mathrm{H}, \mathrm{R}^{2}=\mathrm{Cl} ; \quad 10.6 \mu \mathrm{M}$<smiles>[R]c1ccc(C(c2c[nH]c3ccccc23)c2c[nH]c3ccccc23)cc1</smiles>

3a: $\mathrm{R}=\mathrm{CF}_{3} ; \mathrm{IC}_{50}<10 \mu \mathrm{M}(\mathrm{SW} 480)$

3b: $\mathrm{R}=\mathrm{Ph} ; \mathrm{IC}_{50} \sim 10 \mu \mathrm{M}(\mathrm{SW} 480)$

3c: $\mathrm{R}=\mathrm{OMe}$

3d: $\mathrm{R}=\mathrm{OH}$

3f: $\mathrm{R}=\mathrm{Cl}$<smiles>COc1cc(C(c2c[nH]c3ccccc23)c2c[nH]c3ccccc23)cc(Cl)c1O</smiles>

$\mathrm{IC}_{50}=4.07 \mu \mathrm{M}(\mathrm{MDA}-\mathrm{MB}-231)$<smiles>c1ccc2c(C(c3ccncc3)c3c[nH]c4ccccc34)c[nH]c2c1</smiles>

4

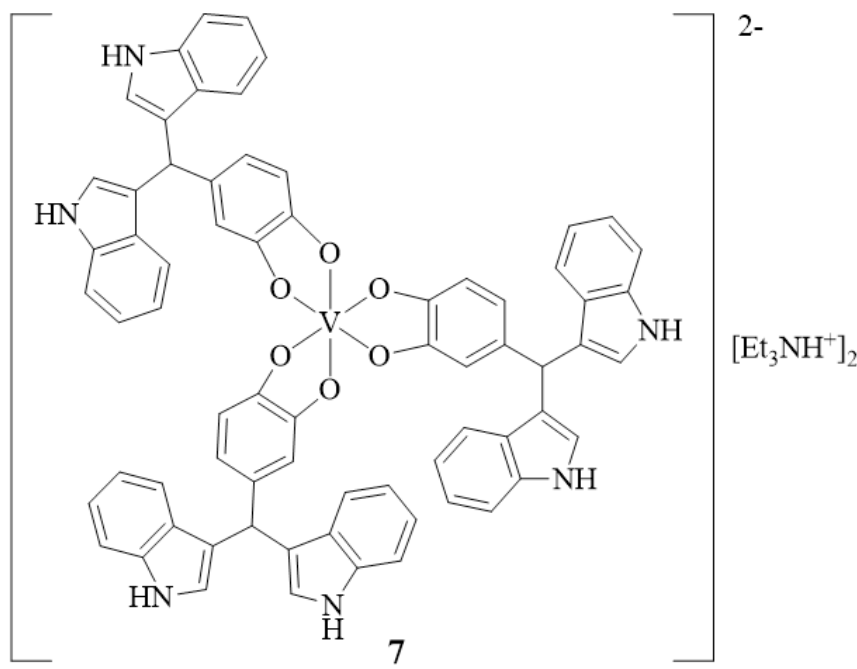

$\mathrm{IC}_{50}=3.0 \mu \mathrm{M}$ (518A2), $8.5 \mu \mathrm{M}$ (HT-29), $1.8 \mu \mathrm{M}$ (HCT-116

wt), $2.1 \mu \mathrm{M}$ (HCT-116 p53-), $6.8 \mu \mathrm{M}$ (KB-V1/Vbl), $2.5 \mu \mathrm{M}$

(MDA-MB-231), $1.8 \mu \mathrm{M}$ (Panc-1), $2.5 \mu \mathrm{M}$ (BxPC-3)

5b: $\mathrm{R}^{1}=\mathrm{Me}, \mathrm{R}^{2}=\mathrm{H}$

5a: $\mathrm{IC}_{50}=1.0 \mu \mathrm{M}(518 \mathrm{~A} 2)$

5c: $\mathrm{IC}_{50}=9.5 \mu \mathrm{M}(518 \mathrm{~A} 2)$<smiles>[R]c1ccc2[nH]c([R])c(C(c3c(F)c(F)c(F)c(F)c3F)c3c([R])[nH]c4ccc([R])cc34)c2c1</smiles>

6a: $\mathrm{R}^{1}, \mathrm{R}^{2}=\mathrm{H}$

6b: $\mathrm{R}^{1}=\mathrm{Me}, \mathrm{R}^{2}=\mathrm{H}$

6c: $\mathrm{R}^{1}=\mathrm{H}, \mathrm{R}^{2}=\mathrm{OMe}$

6a: $\mathrm{IC}_{50}=8.1 \mu \mathrm{M}$ (LNCaP), $13.1 \mu \mathrm{M}(\mathrm{C} 4-2 \mathrm{~B}), 12.9 \mu \mathrm{M}$ (PC3), $12.6 \mu \mathrm{M}(518 \mathrm{~A} 2), 11.3$ $\mu \mathrm{M}(\mathrm{KB}-\mathrm{Vl} / \mathrm{Vbl}), 11.7 \mu \mathrm{M}$ (HT-29);

6b: $\mathrm{IC}_{50}=8.1 \mu \mathrm{M}$ (LNCaP), $6.4 \mu \mathrm{M}(\mathrm{C} 4-2 \mathrm{~B}), 13.1 \mu \mathrm{M}$ (PC3), $10.7 \mu \mathrm{M}$ (518A2), 10.9 $\mu \mathrm{M}(\mathrm{KB}-\mathrm{V} 1 / \mathrm{Vbl}), 9.6 \mu \mathrm{M}$ (HT-29); 6c: $\mathrm{IC}_{50}=6.2 \mu \mathrm{M}(\mathrm{LNCaP})$, $16.5 \mu \mathrm{M}(518 \mathrm{~A} 2), 11.7 \mu \mathrm{M}$ (KB-V1/Vbl), $10.7 \mu \mathrm{M}$ (HT29)

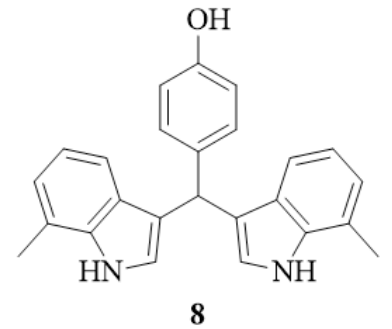

$\mathrm{IC}_{50}=10.9 \mu \mathrm{M}(\mathrm{MDA}-\mathrm{MB}-231)$

Figure 2. Structures of 3,3'-diindolylmethane (DIM) derivatives (halo-, phenyl, and ferrocenyl derivatives) with anti-tumor activities associated with circumvention of cancer resistance. Cell lines (in parentheses): MDA-MB-231 breast cancer, SW480 colon cancer, 518A2 melanoma, LNCaP prostate cancer, C4-2B prostate cancer, PC3 prostate cancer, KB-V1/Vbl cervix cancer, HT-29 colon cancer, HCT-116 colon cancer, Panc-1 pancreas cancer, and BxPC-3 pancreas cancer cells 
analogs at doses of 5, 10, and $15 \mu \mathrm{mol} / \mathrm{L}$ in a luciferase gene reporter assay, and 4 also induced early growth response 1 (Egr-1) activation ${ }^{[50]}$. There is conflicting data on how far the activation of COUP-TFs breast cancer cells can contribute to an anti-tumor treatment. On the one hand, COUP-TF was reported to suppress estrogen-induced gene expression while on the other hand another report described a proliferation promoting activity of COUP-TFI in MCF-7 breast cancer cells ${ }^{[51,52]}$. Hence, more research is necessary in order to find out whether 4 can be a suitable drug candidate for the treatment of breast cancer.

In continuation of this promising synthetic strategy developed by Safe et al ${ }^{[19]}$, organometallic ferrocene derivatives $5 \mathrm{a}-\mathrm{c}$ of DIM were synthesized by our groups, which were tested against various tumor cell lines [Figure 2]. $5 \mathrm{a}\left(\mathrm{IC}_{50}=6.9 \mu \mathrm{mol} / \mathrm{L}\right)$ and $5 \mathrm{~b}\left(\mathrm{IC}_{50}=9.8 \mu \mathrm{mol} / \mathrm{L}\right)$ were much more active than DIM $\left(\mathrm{IC}_{50}\right.$ $=32.1 \mu \mathrm{mol} / \mathrm{L}$ ) against MDA-MB-231 breast cancer cells. Further to this, compounds $5 \mathrm{a}-\mathrm{c}$ reached $\mathrm{IC}_{50}$ values below $5 \mu \mathrm{mol} / \mathrm{L}$ when tested against BxPC-3 pancreas cancer cells where DIM was only moderately active $\left(\mathrm{IC}_{50}=25.2 \mu \mathrm{mol} / \mathrm{L}\right)$. Against DIM-resistant $\left(\mathrm{IC}_{50}>100 \mu \mathrm{mol} / \mathrm{L}\right.$ for $\left.\mathrm{DIM}\right)$ tumor cell lines $518 \mathrm{~A} 2$ melanoma, KB-V1/Vbl cervix carcinoma (i.e., vinblastine-resistant cells) and HT-29 colon carcinoma, compound 5a (DIMFc) was active at doses below $10 \mu \mathrm{mol} / \mathrm{L}\left(\mathrm{IC}_{50}=1.0 \mu \mathrm{mol} / \mathrm{L}\right.$ for $518 \mathrm{~A} 2,3.0 \mu \mathrm{mol} / \mathrm{L}$ for $\mathrm{KB}-\mathrm{V} 1 / \mathrm{Vbl}, 6.3 \mu \mathrm{mol} / \mathrm{L}$ for HT-29) while $5 \mathrm{c}$ was slightly less active $\left(\mathrm{IC}_{50}=9.5 \mu \mathrm{mol} / \mathrm{L}\right.$ for $518 \mathrm{~A} 2,12.6 \mu \mathrm{mol} / \mathrm{L}$ for KB-V1/Vbl, $15.6 \mu \mathrm{mol} / \mathrm{L}$ for HT-29) than 5 a against these tumor cells ${ }^{[53]}$. Ferrocene 5 a overcame DIM resistance in certain tumors; thus, further development of this compound appeared promising. More recently, the pentafluorophenyl derivatives 6a-c (DIMPF series of compounds) also showed distinct activities against MDA-MB-23 breast cancer and BxPC-3 pancreas cancer cells as well. In addition, 6a-c showed significant activity against androgen-dependent (LNCaP) and androgen-independent (C4-2B, PC-3) prostate cancer cells $\left(\mathrm{IC}_{50}=6.2-13.1 \mu \mathrm{mol} / \mathrm{L}\right)$, and they were able to overcome DIM resistance of $518 \mathrm{~A} 2$ melanoma, $\mathrm{KB}-\mathrm{V} 1 / \mathrm{Vbl}$ cervix carcinoma, and HT-29 colon carcinoma cells $\left(\mathrm{IC}_{50}=9.6-16.5 \mu \mathrm{mol} / \mathrm{L}\right)^{[54]}$.

A remarkable non-oxido vanadium (IV) complex 7 with three 3,4-dihydroxyphenyl substituted DIM ligands was also investigated for its anti-tumor activities. Complex 7 exhibited high growth inhibitory activity $\left(\mathrm{IC}_{50}=1.8-3.0 \mu \mathrm{mol} / \mathrm{L}\right)$ against $518 \mathrm{~A} 2$ melanoma, HCT-116 colon carcinoma (both p53-wildtype and p53-negative cells), triple-negative MDA-MB-231 breast cancer, and Panc-1 and BxPC-3 pancreas cancer cells. Additionally, complex 7 showed much higher activity than its metal-free catechol-modified DIM ligand against HT-29 colon cancer $\left(\mathrm{IC}_{50}=8.5 \mu \mathrm{mol} / \mathrm{L}\right.$ for $7,48.9 \mu \mathrm{mol} / \mathrm{L}$ for the ligand) and $\mathrm{KB}$ $\mathrm{V} 1$ - Vbl cervix carcinoma cells $\left(\mathrm{IC}_{50}=6.8 \mu \mathrm{mol} / \mathrm{L}\right.$ for $7,43.7 \mu \mathrm{mol} / \mathrm{L}$ for the ligand). The mechanisms of complex 7 were studied, and 7 interacted with DNA as shown in ethidium bromide assays, caused mitochondrial damage, produced reactive oxygen species (ROS), and led to $\mathrm{G}_{2} / \mathrm{M}$ cell cycle arrest in 518A2 melanoma cells ${ }^{[55]}$.

The 4-hydroxyphenyl derivative 8 (phemindole) is another DIM derivative with distinct and selective growth inhibitory activity against MDA-MB-231 breast cancer cells $\left(\mathrm{IC}_{50}=10.9 \mu \mathrm{mol} / \mathrm{L}\right)$ and 8 was much more active than DIM $\left(\mathrm{IC}_{50}=72.3 \mu \mathrm{mol} / \mathrm{L}\right)$ against these cancer cells. Compound 8 induced mitochondriabased apoptosis and ROS formation as well as endoplasmic reticulum (ER) stress by suppression of stromal interacting molecule 1 (STIM1) and store operated calcium entry (SOCE). In vivo experiments with 4 T1 breast tumor bearing mice showed that 8 at doses of $10 \mathrm{mg} / \mathrm{kg}$ and $15 \mathrm{mg} / \mathrm{kg}$ (intravenously) was able to inhibit breast tumor growth significantly, which indicates that 8 possesses a reasonable bioavailability ${ }^{[56]}$.

Various formulations were described for Safe and colleagues' para-substituted DIM-P (phenyl-DIM) derivatives. A spray-dried enteric coated self-emulsified drug delivery system (Spray BIO-Max) was applied for the formulation of DIM-Ps, which led to increased oral bioavailability and to enhanced lung tumor weight /volume reduction in mice with $\mathrm{H} 1650$ metastatic tumors (20\%-25\% greater reduction) or A549 orthotopic tumors (25\%-30\% greater reduction) than DIM-P solution alone ${ }^{[57]}$. Similarly, nano-structured lipid carrier (NLC) formulations and self-emulsifying drug (SED) delivery formulations of DIM derivatives 
<smiles>CCCCCCCC(c1cn(C2OC(CO)C(O)C(O)C2O)c2ccc(Br)cc12)c1cn(C2OC(CO)C(O)C(O)C(O)C2O)c2ccc(Br)cc12</smiles>

9

$\mathrm{IC}_{50}=0.8 \mu \mathrm{M}(\mathrm{PC} 3)$

$5.9 \mu \mathrm{M}(\mathrm{DU}-145)$

$2.8 \mu \mathrm{M}(\mathrm{MiaPaCa}-2)$

$5.3 \mu \mathrm{M}(\mathrm{COLO}-205)$

$2.5 \mu \mathrm{M}$ (HUVEC)

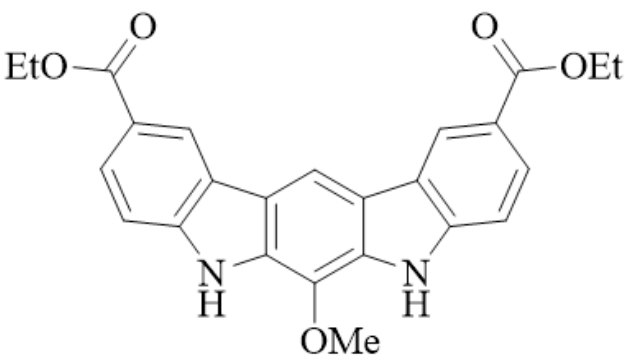

11<smiles>Oc1ccc2[nH]cc(C(c3ccc(C(c4c[nH]c5ccc(O)cc45)c4c[nH]c5ccc(O)cc45)cc3)c3c[nH]c4ccc(O)cc34)c2c1</smiles>

10

$\mathrm{IC}_{50}=0.45 \mu \mathrm{M}(\mathrm{MDA}-\mathrm{MB}-231)$,

$0.88 \mu \mathrm{M}(\mathrm{MCF}-7)$<smiles>N#Cc1ccc(C2c3[nH]c4ccccc4c3C(c3ccc(C#N)cc3)c3[nH]c4ccccc4c32)cc1</smiles>

$\mathrm{IC}_{50}=5.7 \mu \mathrm{M}(\mathrm{MCF}-7)$

Figure 3. Structures of anti-tumor active 3,3'-diindolylmethane (DIM) derivatives (glycosides, tetraindole, and stabilized derivatives). Cell lines: A549 lung cancer, HeLa cervix cancer, MCF-7 breast cancer, PC3 prostate cancer, DU-145 prostate cancer, MiaPaCa-2 pancreas cancer, COLO-205 colon cancer, MDA-MB-231 breast cancer, SKOV-3 ovarian cancer, and HUVEC endothelial cells

revealed promising anticancer results in TNBC (MDA-MB-231) and lung tumor (H1650) models aside improved oral bioavailability ${ }^{[58,59]}$.

A series of $\mathrm{N}$-glycosides of DIM was prepared and tested for anti-tumor activity [Figure 3]. Compound 9 (NGD16) exhibited the highest tumor cell growth inhibitory activity of this series $\left(\mathrm{IC}_{50}=1.3 \mu \mathrm{mol} / \mathrm{L}\right.$ for A549 lung, $0.3 \mu \mathrm{mol} / \mathrm{L}$ for HeLa cervix, and $0.9 \mu \mathrm{mol} / \mathrm{L}$ for MCF-7 breast cancer cells), and induced apoptosis by upregulation of pro-apoptotic Par-4 (prostate apoptosis response 4) accompanied by suppression of Bcl-2 and GRP78 (glucose regulated protein $78 \mathrm{kDa}$ ). In addition, 9 inhibited the migration of HeLa cells and arrested the cell cycle in the G1 phase ${ }^{[60]}$. Compound 9 also inhibited the growth of moderately aggressive PC3 $\left(\mathrm{IC}_{50}=0.8 \mu \mathrm{mol} / \mathrm{L}\right)$ and DU-145 prostate cancer cells $\left(\mathrm{IC}_{50}=5.9 \mu \mathrm{mol} / \mathrm{L}\right)$, MiaPaCa-2 pancreas cancer cells $\left(\mathrm{IC}_{50}=2.8 \mu \mathrm{mol} / \mathrm{L}\right), \mathrm{COLO}-205$ colon cancer cells $\left(\mathrm{IC}_{50}=5.3 \mu \mathrm{mol} / \mathrm{L}\right)$, and HUVECS $\left(\mathrm{IC}_{50}=2.5 \mu \mathrm{mol} / \mathrm{L}\right)$. The high activity against HUVECs suggested an anti-angiogenic mode of action for 9. Indeed, compound 9 inhibited angiogenesis by suppression of GRP78, VEGFR2 (vascular 


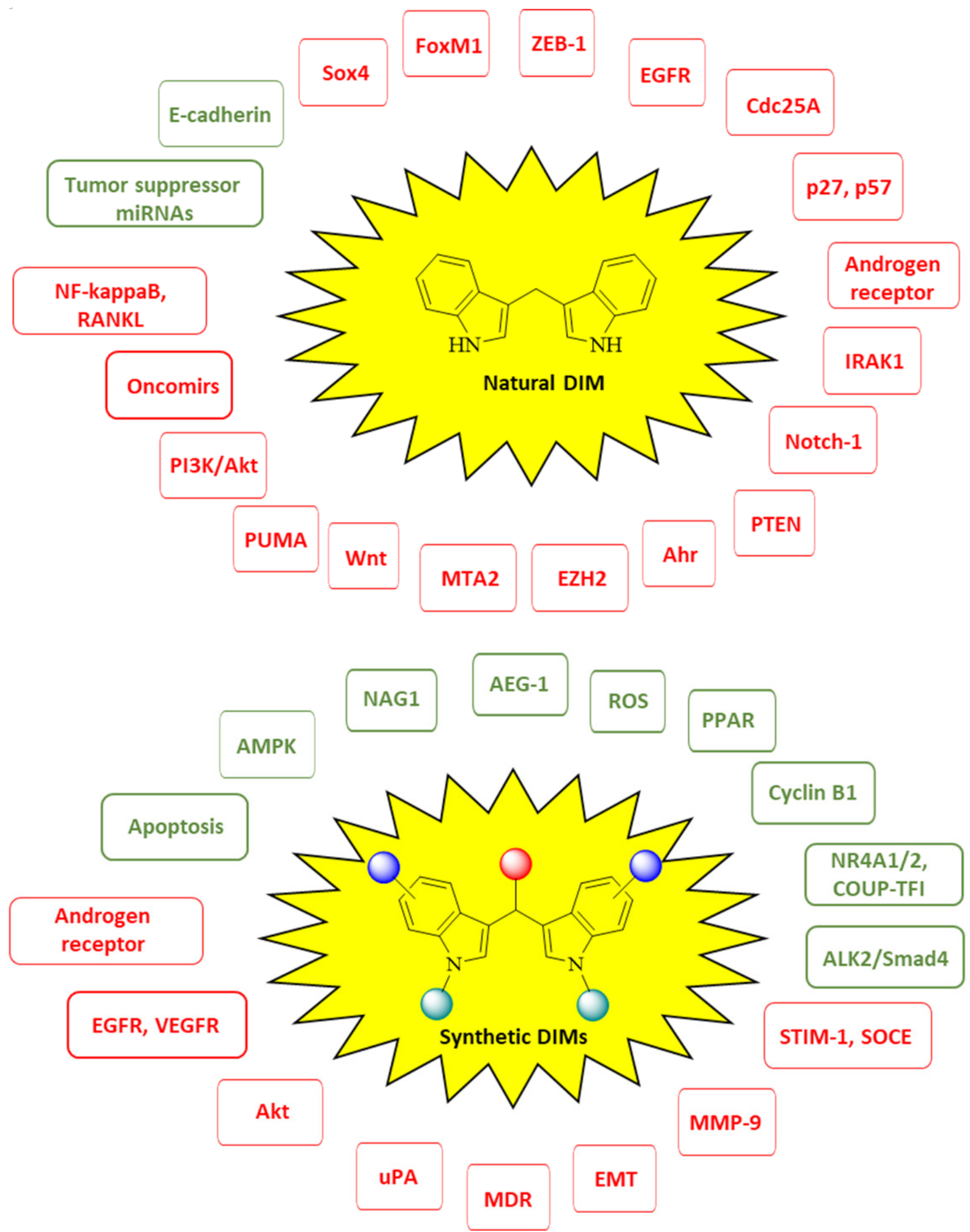

Figure 4. Targets of natural 3,3'-diindolylmethane (DIM) and synthetic DIM derivatives (green = activated targets, red = suppressed/ inhibited targets)

endothelial growth factor receptor 2), and matrix metalloproteinase-9 (MMP-9) expression, and cancer cells treated with 9 showed a translocation of GRP78 to the cell membrane and interaction of GRP78 with 
tissue inhibitor of metalloproteinase-1 (TIMP-1 $)^{[61]}$. Since Par-4 is a known inhibitor of tumor invasion, epithelial-to-mesenchymal transition, and mesenchymal markers, compound 9 was also studied for its inhibitory effects on the epithelial-to-mesenchymal transition. In pancreas cancer cells, 9 induced Par- 4 leading to the suppression of vimentin, Twist-1, and Sox2. Additionally, ALK2/Smad4 signaling was induced by 9 via Par- 4 activation. Hence, compound 9 appeared to be a promising drug candidate for the treatment and prevention of metastatic pancreas cancer ${ }^{[62]}$.

The tetraindole 10 (SK228) prepared from terephthalaldehyde and 5-hydroxyindole showed higher activity against triple-negative MDA-MB-231 breast cancer cells $\left(\mathrm{IC}_{50}=0.45 \mu \mathrm{mol} / \mathrm{L}\right)$ than against hormonesensitive MCF- 7 breast cancer cells $\left(\mathrm{IC}_{50}=0.88 \mu \mathrm{mol} / \mathrm{L}\right)^{[63]}$. Compound 10 led to $\mathrm{G}_{2}$ cell cycle arrest by upregulation of cyclin B1 expression and phosphor-cdc-2 in the breast cancer cells. The stable DIM derivative 11 (SR13668) conserved the Akt suppressing properties of I3C and DIM in PC3 prostate cancer cells and inhibited the growth of triple-negative MDA-MB-231 breast tumors, androgen-independent PC-3 prostate tumors, and drug-resistant SKOV-3 ovarian tumors in vivo indicating a reasonable bioavailability of $11^{[64]}$. Tetrahydroindolocarbazoles are further promising structural analogs of DIM, and compound 12 showed activity against MCF-7 breast cancer cells $\left(\mathrm{IC}_{50}=5.7 \mu \mathrm{mol} / \mathrm{L}\right) .12$ inhibited the tumor-promoting factor uPA (urokinase plasminogen activator) which is overexpressed in various cancers including breast cancer $^{[65]}$.

\section{CONCLUSION}

There is growing evidence that natural DIM and synthetic DIM derivatives are useful tools in order to overcome cancer drug resistance. These drug candidates use diverse and manifold mechanisms in order to break resistance or to re-sensitize resistant tumors for approved anticancer drugs [Figure 4]. Certain DIM derivatives were even active against DIM resistant tumor cell lines, others showed promising in vivo activities against metastatic and drug-resistant tumor models. In addition, valuable formulation strategies were developed in order to increase the bioavailability of DIM and of some of its derivatives and to enhance their in vivo anti-tumor activity. These strategies appear also to be useful for the formulation of other existing or future DIM derivatives with similar bioavailability problems.

\section{DECLARATIONS}

\section{Authors' contributions}

The author contributed solely to the article.

\section{Availability of data and materials}

Not applicable.

\section{Financial support and sponsorship}

None.

\section{Conflicts of interest}

The author declared that there are no conflicts of interest.

\section{Ethical approval and consent to participate}

Not applicable.

\section{Consent for publication}

Not applicable.

\section{Copyright}

(c) The Author(s) 2020. 


\section{REFERENCES}

1. Urruticoechea A, Alemany R, Balart J, Villanueva A, Vinals F, et al. Recent advances in cancer therapy: an overview. Curr Pharm Des 2010;16:3-10.

2. Baskar R, Lee KA, Yeo R, Yeoh KW. Cancer and radiation therapy: current advances and future directions. Int J Med Sci 2012;9:193-9.

3. Khalil DN, Smith EL, Brentjens RJ, Wolchok JD. The future of cancer treatment: immunomodulation, CARs and combination immunotherapy. Nat Rev Clin Oncol 2016;13:273-90.

4. Wang X, Zhang H, Chen X. Drug resistance and combating drug resistance in cancer. Cancer Drug Resist 2019;2:141-60.

5. Kumar S, Kushwaha PP, Gupta S. Emerging targets in cancer drug resistance. Cancer Drug Resist 2019;2:161-77.

6. Johnson IS, Armstrong JG, Gorman M, Burnett Jr JP. The Vinca alkaloids: a new class of oncolytic agents. Cancer Res 1963;23:1390-427.

7. Biersack B, Schobert R. Indole compounds against breast cancer: recent developments. Curr Drug Targets 2012;13:1705-19.

8. Omura S, Iwai Y, Hirano A, Nakagawa A, Awaya J, et al. A new alkaloid AM-2282 of Streptomyces origin. Taxonomy, fermentation, isolation and preliminary characterization. J Antibiot 1977;30:275-82.

9. Oudard S, Beuselinck B, Decoene J, Albers P. Sunitinib for the treatment of metastatic renal cell carcinoma. Cancer Treat Rev 2011;37:178-84.

10. Bourhill T, Narendran A, Johnston RN. Enzastaurin: a lesson in drug development. Crit Rev Oncol Hematol 2017;112:72-9.

11. Sarkar FH, Li Y. Harnessing the fruits of nature for the development of multi-targeted cancer therapeutics. Cancer Treat Rev 2009;35:597-607.

12. Ahmad A, Biersack B, Li Y, Kong D, Bao B, et al. Target regulation of PI3K/Akt/mTOR/NF-kB signaling by indole compounds and their derivatives: mechanistic details and biological implications for cancer therapy. Anti-Cancer Agents Med Chem 2013;13:1002-13.

13. Ahmad A, Sakr WA, Rahman KM. Anticancer properties of indole compounds: mechanism of apoptosis induction and role in chemotherapy. Cancer Treat Rev 2009;35:597-607.

14. Terry P, Wolk A, Persson I, Magnusson C. Brassica vegetables and breast cancer risk. JAMA 2001;285:2975-7.

15. Keck AS, Finley JW. Cruciferous vegetables: cancer protective mechanisms of glucosinolate hydrolysis products and selenium. Integr Cancer Ther 2004;3:5-12.

16. Paltsev M, Kiselev V, Muyzhnek E, Drukh V, Kuznetsov I, et al. Comparative preclinical pharmacokinetics study of 3,3'-diindolylmethane formulations: is personalized treatment and targeted chemoprevention in the horizon? EPMA J 2013;4:25.

17. Kaishap PP, Dohutia C. Synthetic approaches for bis(indolyl)methanes. Int J Pharm Sci Res 2013;4:1312-22.

18. Shiri M, Zolfigol MA, Kruger HG, Tanbakouchian Z. Bis- and trisindolylmethanes (BIMs and TIMs). Chem Rev 2010;110:2250-93.

19. Safe S, Papineni S, Chintharlapalli S. Cancer chemotherapy with indole-3-carbinol, bis(3'-indolyl)methane and synthetic analogs. Cancer Lett 2008;269:326-38.

20. Li Y, Kong D, Ahmad A, Bao B, Sarkar FH. Antioxidant function of isoflavone and 3,3'-diindolylmethane: are they important for cancer prevention and therapy. Antioxid Redox Signal 2013;19:139-50.

21. Popolo A, Pinto A, Daglia M, Nabavi SF, Farooqi AA, et al. Two likely targets for the anti-cancer effect of indole derivatives from cruciferous vegetables: PI3K/Akt/mTOR signaling pathway and the aryl hydrocarbon receptor. Seminars Cancer Biol 2017;46:132-7.

22. Wang S, Cheng L, Liu Y, Wang J, Jiang W. Indole-3-carbinol (I3C) and its major derivatives: their pharmacokinetics and important roles in hepatic protection. Curr Drug Metabol 2016;17:401-9.

23. Reed GA, Sunega JM, Sullivan DK, Gray JC, Mayo MS, et al. Single-dose pharmacokinetics and tolerability of absorption-enhanced 3,3'-diindolylmethane in healthy subjects. Cancer Epidemiol Biomarkers Prev 2008;17:2619-24.

24. Amare DE. Anti-cancer and other biological effects of a dietary compound 3,3'-diindolylmethane supplementation: a systematic review of human clinical trials. Nutr Diet Suppl 2020;12:123-37.

25. Heath EI, Heilbrun LK, Li J, Vaishampayan U, Harper F, et al. A phase I dose-escalation study of oral BR-DIM (BioResponse 3,3'-Diindolylmethane) in castrate-resistant, non-metastatic prostate cancer. Am J Transl Res 2010;2:402-11.

26. Hwang C, Sethi S, Heilbrun LK, Gupta NS, Chitale DA, et al. Anti-androgenic activity of absorption-enhanced 3,3'-diindolylmethane in prostatectomy patients. Am J Transl Res 2016;8:166-76.

27. Gee JR, Saltzstein DR, Messing E, Kim KM, Kolesar J, et al. Phase Ib placebo-controlled, tissue biomarker trial of diindolylmethane (BR-DIMNG) in patients with prostate cancer who are undergoing prostatectomy. Eur J Cancer Prev 2016;25:312-20.

28. Thomson CA, Chow HHS, Wertheim BC, Roe DJ, Stopeck A, et al. A randomized, placebo-controlled trial of diindolylmethane for breast cancer biomarker modulation in patients taking tamoxifen. Breast Cancer Res Treat 2017;165:97-107.

29. Biersack B. Non-coding RNA/microRNA-modulatory dietary factors and natural products for improved cancer therapy and prevention: alkaloids, organosulfur compounds, aliphatic carboxylic acids and water-soluble vitamins. Non-Coding RNA Res 2016;1:51-63.

30. Kong D, Heath E, Chen W, Cher ML, Powell I, et al. Loss of let-7 upregulates EZH2 in prostate cancer consistent with the acquisition of cancer stem cell signatures that are attenuated by BR-DIM. PLoS One 2012;7:e33729.

31. Kashat M, Azzouz L, Sarkar SH, Kong D, Li Y, et al. Inactivation of AR and Notch-1 signaling by miR-34a attenuates prostate cancer aggressiveness. Am J Transl Res 2012;4:432-42.

32. Yu J, Feng Y, Wang Y, An R. Aryl hydrocarbon receptor enhances the expression of miR-150-5p to suppress in prostate cancer progression by regulating MAP3K12. Arch Biochem Biophys 2018;654:47-54.

33. Ahmad A, Ali S, Ahmed A, Ali AS, Raz A, et al. Diindolylmethane enhances the effectiveness of Herceptin against HER-2/neu-expressing breast cancer cells. PLoS One 2013;8:e54657.

34. Hanieh H. Aryl hydrocarbon receptor-microRNA-212/132 axis in human breast cancer suppresses metastasis by targeting SOX4. Mol Cancer 2015;14:172. 
35. Li Y, Vandenbloom II TG, Kong D, Wang Z, Ali S, et al. Up-regulation of miR-200 and let-7 by natural agents leads to the reversal of epithelial-to-mesenchymal transition in gemcitabine-resistant pancreatic cancer cells. Cancer Res 2009;69:6704-12.

36. Li Y, Vandenbloom II TG, Wang Z, Kong D, Ali S, et al. MiR-146a suppresses invasion of pancreatic cancer cells. Cancer Res 2010;70:1486-95.

37. Li Y, Kong D, Ahmad A, Bao B, Sarkar FH. Targeting bone remodeling by isoflavone and 3,3'-diindolylmethane in the context of prostate cancer bone metastasis. PLoS One 2012;7:e33011.

38. Sarkar S, Dubayo H, Ali S, Goncalves P, Kollepara SL, et al. Down-regulation of miR-221 inhibits proliferation of pancreatic cancer cells through up-regulation of PTEN, p27(kip1), p57 (kip2), and PUMA. Am J Cancer Res 2013;3:465-77.

39. Jin Y. 3,3'-Diindolylmethane inhibits breast cancer cell growth via miR-21-mediated CDC25A degradation. Mol Cell Biochem 2011;358:345-54.

40. Junaid M, Dash R, Islam N, Chowdhury J, Alam MJ, et al. Molecular simulation studies of 3,3'-diindolylmethane as a potent microRNA-21 antagonist. J Pharm Bioallied Sci 2017;9:259-65.

41. Bhowmik A, Das N, Pal U, Mandal M, Bhattacharya S, et al. 2,2'-Diphenyl-3,3'-diindolylmethane: a potent compound induces apoptosis in breast cancer cells by inhibiting EGFR pathway. PLoS One 2013;8:e59798.

42. Abdelbaqi K, Lack N, Guns ET, Kotha L, Safe S, et al. Antiandrogenic and growth inhibitory effects of ring-substituted analogs of 3,3'-diindolylmethane (ring-DIMs) in hormone-responsive LNCaP human prostate cancer cells. Prostate 2011;71:1401-12.

43. Goldberg AA, Titorenko VI, Beach A, Abdelbaqi K, Safe S, et al. Ring-substituted analogs of 3,3'-diindolylmethane (DIM) induce apoptosis and necrosis in androgen-dependent and -independent prostate cancer cells. Invest New Drugs 2014;32:25-36.

44. Draz H, Goldberg AA, Titorenko VI, Guns EST, Safe S, et al. Diindolylmethane and its halogenated derivatives induce protective autophagy in human prostate cancer cells via induction of the oncogenic protein AEG-1 and activation of AMP-activated protein kinase. Cell Signal 2017;40:172-82.

45. Chintharlappali S, Papineni S, Safe S. 1,1-Bis(3'-indolyl)-1-(p-substituted phenyl)methanes inhibit colon cancer cell and tumor growth through PPARgamma-dependent and PPARgamma-independent pathways. Mol Cancer Ther 2006;5:1362-70.

46. Yoon K, Lee SO, Cho SD, Kim K, Kham S, et al. Activation of nuclear TR3 (NR4A1) by a diindolylmethane analog induces apoptosis and proapoptotic genes in pancreatic cancer cells and tumors. Carcinogenesis 2011;32:836-42.

47. Hedrick E, Cheng Y, Lacey A, Mohankumar K, Zarel M, et al. Potent inhibition of breast cancer by bis-indole-derived nuclear receptor 4A1 (NR4A1) antagonists. Breast Cancer Res Treat 2019;177:29-40.

48. Li X, Tjalkens RB, Shrestha R, Safe S. Structure-dependent activation of gene expression by bis-indole and quinolone-derived activators of nuclear receptor 4A2. Chem Biol Drug Des 2019;94:1711-20.

49. Boakye CHA, Patel K, Patel AR, Faria HAM, Zuculotto V, et al. Lipid-based oral delivery systems for skin deposition of a potential chemopreventive DIM derivative: characterization and evaluation. Drug Deliv Transl Res 2016;6:526-39.

50. Yoon K, Chen CC, Orr AA, Barreto PN, Tamamis P, et al. Activation of Coup-TFI by a novel diindolylmethane derivative. Cells 2019;220.

51. Klinge CM, Silver BF, Driscoll MD, Sathya G, Bambara RA, et al. Chicken ovalbumin upstream promoter-transcription factor interacts with estrogen receptor response elements and half-sites, and inhibits estrogen-induced gene expression. J Biol Chem 1997;272:31465-74.

52. Le Dily F, Metivier R, Gueguen MM, Le Peron C, Flouriot G, et al. COUP-TFI modulates estrogen signaling and influences proliferation, survival and migration of breast cancer cells. Breast Cancer Res Treat 2008;110:69-83.

53. Muenzner JK, Ahmad A, Rothemund M, Schrüfer S, Padhye S, et al. Ferrocene-substituted 3,3'-diindolylmethanes with improved anticancer activity. Appl Organometal Chem 2016;30:441-5.

54. Ahmad A, Dandawate P, Schruefer S, Padhye S, Sarkar FH, et al. Pentafluorophenyl substitution of natural di(indolyl-3-yl)methane strongly enhances growth inhibition and apoptosis induction in various cancer cell lines. Chem Biodiversity 2019;16:e1900028.

55. Dankhoff K, Ahmad A, Weber B, Biersack B, Schobert R. Anticancer properties of a new non-oxido vanadium(IV) complex with a catechol-modified 3,3'-diindolylmethane ligand. J Inorg Biochem 2019;194:1-6.

56. Chakraborty S, Ghosh S, Banerjee B, Santra A, Adhikary A, et al. Phemindole, a synthetic di-indole derivative maneuvers the store operated calcium entry (SOCE) to induce potent anti-carcinogenic activity in human triple negative breast cancer cells. Front Pharmacol 2016;7:114.

57. Patel AR, Godugu C, Wilson H, Safe S, Singh M. Evaluation of spray BIO-Max DIM-P in dogs for oral bioavailability and in Nu/nu mice bearing orthotopic/metastatic lung tumor models for anticancer activity. Pharm Res 2015;32:2292-300.

58. Godugu C, Doddapaneni R, Safe SH, Singh M. Novel diindolylmethane derivatives based NLC formulations to improve the oral bioavailability and anticancer effects in triple negative breast cancer. Eur J Pharm Biopharm 2016;108:168-79.

59. Patel AR, Doddapaneni R, Andey T, Wilson H, Safe S, et al. Evaluation of self-emulsified DIM-14 in dogs for oral bioavailability and in $\mathrm{Nu} / \mathrm{nu}$ mice bearing stem cell lung tumor models for anticancer activity. J Controlled Release 2015;213:18-26.

60. Sharma DK, Rah B, Lambu MR, Hussain A, Yousuf SK, et al. Design and synthesis of novel N,N'-glycoside derivatives of 3,3'-diindolylmethanes as potential antiproliferative agents. Med Chem Commun 2012;3:1082-91.

61. Nayak D, Amin H, Rah B, Sharma D, Rasool RU, et al. Synthesis, pharmacodynamics and pharmacokinetic evaluation of a novel, therapeutically relevant N-glycosylated derivative of DIM (NGD16) as potential inhibitor of angiogenesis. J Cancer Sci Ther 2014;6:278-88.

62. Katoch A, Suklabaidya S, Chakraborty S, Nayak D, Rasool RU, et al. Dual role of Par-4 in abrogation of EMT and switching on mesenchymal to epithelial transition (MET) in metastatic pancreatic cancer cells. Mol Carcinogenesis 2018;57:1102-15.

63. Li WS, Wang CH, Ko S, Chang TT, Jen YC, et al. Synthesis and evaluation of the cytotoxicities of tetraindoles: observation that the 
5-hydroxy tetraindole (SK228) induces $\mathrm{G}_{2}$ arrest and apoptosis in human breast cancer cells. J Med Chem 2012;55:1583-92.

64. Chao WR, Yean D, Amin K, Green C, Jong L. Computer-aided rational drug design: a novel agent (SR13668) designed to mimic the unique anticancer mechanisms of dietary indole-3-carbinol to block Akt signaling. J Med Chem 2007;50:3412-5.

65. Ahmed EM, Sarhan AE, El-Naggar DH, Khattab RR, El-Naggar M, et al. Towards breast cancer targeting: synthesis of tetrahydroindolocarbazoles, antibreast cancer evaluation, uPA inhibition, molecular genetic and molecular modelling studies. Bioorg Chem 2019;93:103332. 